
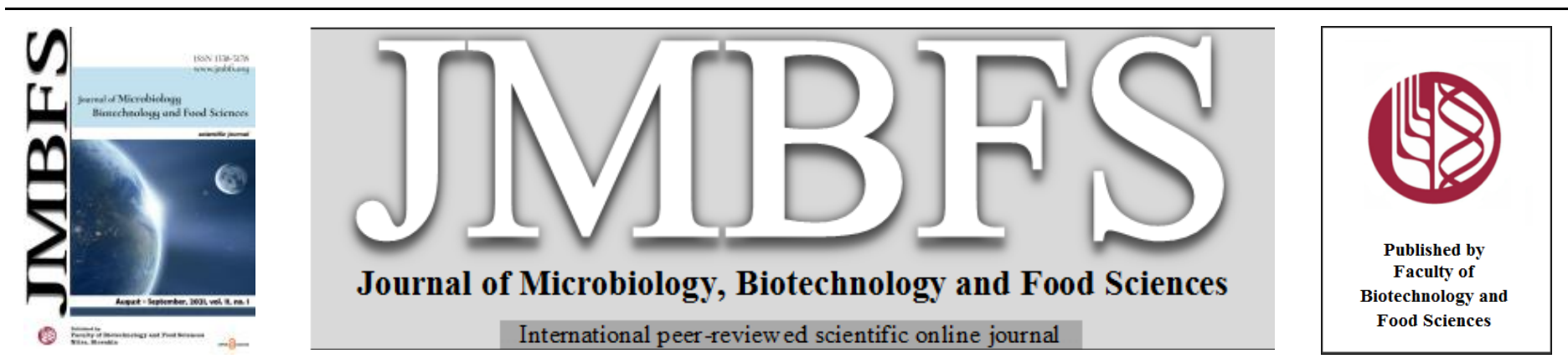

\title{
USE OF BRAZIL NUT KERNELS IN STUFFED MEAT TECHNOLOGY
}

\author{
Aleksandr Lukin $*^{l}$, Natalya Naumova ${ }^{l}$, Julia Betz ${ }^{1}$
}

\begin{abstract}
Address(es):
${ }^{1}$ Federal State Autonomous Educational Institution of Higher Education "South Ural State University (national research university)", Department of Higher School of Food and Biotechnology, 454080 Chelyabinsk, Russia.
\end{abstract}

*Corresponding author: lukin3415@gmail.com

https://doi.org/10.15414/jmbfs.4014

\section{ARTICLE INFO}

Received 29. 11. 2020

Revised 27. 1. 2021

Accepted 4. 2. 2021

Published 1. 8. 2021

Regular article

open PACCESS

\section{ABSTRACT}

The results of the use of Brazil nut kernels in the technology of stuffed meat products are presented. The composition and physicochemical parameters of plant and meat raw materials have been tested. It has been determined that the content of lipids and mineral elements in the kernels of the nut exceeds their amounts established in chilled legs of broiler chickens. The addition of plant material at a dosage of $10 \%$ improves the taste and aroma properties and increases the content of $\mathrm{Ca}$ (2.2 times), Se ( 2 times), $\mathrm{Fe}$ (1.7 times), $\mathrm{Mg}$ (1.6 times), $\mathrm{P}$ and $\mathrm{Zn}$ (by 26\%) in the finished product against the background of a decrease in the amount of butter according to the recipe by $8 \%$. The use of Brazil nuts also introduces microelements ( $\mathrm{Cu}, \mathrm{Mn}, \mathrm{Mo}, \mathrm{Ag}, \mathrm{Au}, \mathrm{Co})$ and dietary fiber into the meat product.

Keywords: stuffed meat products, semi-finished products from meat of broiler chickens, Brazil nuts

\section{INTRODUCTION}

Meat products are undoubtedly the primary source of complete proteins, fats, vitamins (B, PP) and minerals ( $\mathrm{Fe}, \mathrm{P}, \mathrm{Zn}, \mathrm{Cu}, \mathrm{Cr}$, etc.) (Choi et al., 2014; Lisitsyn et al., 2016). However, they lack complex carbohydrates such as dietary fiber, pectin, as well as organic acids, flavonoids, phytosterols, and other components that are found in plant raw materials and can improve the product quality and make it a functional food product. In this regard, there have been developed technologies for the production of chicken cutlets with flax seeds (Baturina and Babenko, 2019), canned meat and vegetables containing cabbage, zucchini, carrots (Lisovitskaya and Patieva, 2016), ground pork and beef with the addition of beet fibers (Akhmedova, 2015), meat products with the addition of Jerusalem artichoke flour (Petchenko et al., 2016), meat pâté with honey-nut extract (Gorlov et al., 2020), etc. Today, the Brazilian nut is considered a great source of complete protein, mineral elements ( $\mathrm{Se}, \mathrm{Cu}, \mathrm{Mn}, \mathrm{I}$ ), fatty acids (palmitic, stearic, linoleic, oleic), individual vitamins (groups B, E), and fiber (Klimova, 2008; Martins et al., 2014; Kantoroeva, 2019; Ionescu et al., 2011; Jamshed et al., 2015)

Brazil nuts are widely used in recipes for curd cheeses, cereal bars, nut and seed butters to increase their nutritional value (Ukkonen and Belozerova, 2017; Patent No. 2706159 RF; Patent No. 2603892 RF). The aim of the research was to study the possibility of using Brazil nut kernels in the technology of stuffed meat products with increased nutritional value.

\section{MATERIAL AND METHODS}

The following was used as materials of the research:

- chilled chicken legs (semi-finished broiler chicken product) produced by OAO Turbaslinskiye Broilery (Republic of Bashkortostan, Blagoveshchensk) in accordance with GOST 31962-13;

- kernels of Brazil nuts from Bolivia manufactured by OOO Komservis (Moscow Region, Mytishchi) in accordance with TU 9760-002-76440635-16;

- Chicken pockets with butter and herbs cooked according to TU 9214-01364474310-12 by way of baking stuffed broiler chicken legs at $200{ }^{\circ} \mathrm{C}$ for 20 minutes. Control samples were cooked according to a traditional recipe (Table 1), test samples were cooked adding crushed Brazil nut kernels in the amount of $5 \%$ (test 1 ), $10 \%$ (test 2), 15\% (test 3 ) and $4 \%, 8 \%, 12 \%$ less butter accordingly. Test samples of chicken pockets were cooked using deboned chicken legs with skin, flat in shape, with a longitudinal cut in the form of a pocket filled with butter, mixed herbs, ground dried apples, and Brazil nut kernels. The cut was joined with wooden skewers.
- Letniy Sad food additive produced by OOO Kulmbakh-D (Moscow Region, Krasnoarmeysk) in accordance with TU 10.89.19-008-58251238-20. Ingredients: dill, garlic, mustard, table salt, maltodextrin, dextrose, E621, dill extract, caraway extract, E100;

$\underline{\text { Table } 1 \text { Recipe for Chicken Pockets with Oil and Herbs }}$

\begin{tabular}{lc}
\hline Ingredients & Amount, kg \\
\hline Deboned chicken legs & 80.0 \\
\hline Butter $82.5 \%$ fat & 19.5 \\
\hline Letniy Sad herbs mix & 0.5 \\
\hline
\end{tabular}

Chicken legs used as a raw material were washed and dried. Then, a "pocket" was formed by separating the muscle tissue and skin from the bone. To do so, there was made an incision in the muscle tissue along the bone. The muscle tissue together with the skin was turned inside out. The exposed bone was cut off at the base of the tendon. Next, the formed "pocket" was filled with butter, apple powder, and ground Brazil nuts. The filling was sprinkled with Letniy Sad herbs mix. The open ends of the "pocket" were closed with skewers. The obtained semi-finished products were heat-treated in a convection steamer at a temperature of $180-200{ }^{\circ} \mathrm{C}$ in the baking mode.

The plant raw material was tested for the content of protein and fat according to MU 4237-86, sugar - GOST 8756.13-87, starch - using standard approach. The meat and meat products were tested for protein according to GOST 25011-2017, fat - GOST 23042-2015, moisture - GOST 9793-2016, table salt - GOST 99572015. Sensory evaluation was carried out according to GOST 9959-2015 using 9point scale. The content of dietary fiber in all samples was studied using the traditional approach, mineral elements - using iCAP 7200 DUO emission spectrometer (Skurikhin and Tutelyan, 1998).

The method determining soluble and insoluble dietary fiber is based on the enzymatic hydrolysis of starch and non-starch compounds using ó-amylase, protease, and amyloglucosidase to mono-, di-, oligosaccharides, and peptides. Dietary fiber is precipitated with ethyl alcohol, then dried and calculated using the gravimetric analysis.

The principle of this type of analysis is based on registering the spectra of the elements under study when the aerosol of the sample enters the source of the inductively coupled plasma, measuring the emission level of atoms and ions, and determining the mass concentration of the elements under study using the calibration curves.

All analyses were carried out in triplicate unless otherwise stated and the average values were calculated. The results were expressed as mean value \pm standard 
deviation. Significant differences between mean values at significance level $\mathrm{p}<$ 0.05 were established using the One-way analysis of variance and Student's test. Microsoft Excel version 2010 was used as the statistical analysis software.

\section{RESULTS AND DISCUSSION}

The kernels of Brazil nuts proved to have a relatively high content of lipids (Table 2), which made it possible to decrease the amount of butter in the recipe, and thus to reduce the content of cholesterol and increase the level of polyunsaturated fatty acids in the test samples of chicken pockets (Evsenina and Nikitov, 2019). Most of these acids being part of phospholipids serve as a source of energy, participate in building cell membranes and the synthesis of hormonelike biologically active substances - eicosanoids (Simopoulos, 2010; Amariei et al., 2016).

Sugars, starch, and dietary fiber were also found in the kernels. Dietary fiber is known to support the work of gastrointestinal tract, prevent metabolic disorders (excess body weight, obesity, hyperlipidemia), and reduce the risk of developing cardiovascular and oncological diseases (Pyreva and Safronova, 2019; Souza $\boldsymbol{e}$ al., 2015)

Table 2 Nutrient Composition of Material under Study

\begin{tabular}{lcc}
\hline \multirow{2}{*}{ Indicator } & \multicolumn{2}{c}{ Results of Raw Material Study } \\
\cline { 2 - 3 } & chicken legs & Brazil nut \\
\hline Mass fraction of protein, \% & $18.3 \pm 1.6$ & $18.7 \pm 1.5$ \\
\hline Mass fraction of fat, \% & $6.2 \pm 0.5$ & $67.5 \pm 3.3$ \\
\hline Sugar content, \% & - & $2.70 \pm 0.16$ \\
\hline Starch content, \% & - & $0.30 \pm 0.02$ \\
\hline $\begin{array}{l}\text { Dietary fiber content, g /100 g, } \\
\text { including }\end{array}$ & & $7.4 \pm 0.4$ \\
soluble & - & $1.9 \pm 0.3$ \\
insoluble & - & $5.5 \pm 0.4$ \\
\hline
\end{tabular}

The mineral composition of the non-traditional plant component turned out to be richer than that of broiler chicken legs in terms of the number of elements (Table 3 ). In terms of the content of micronutrients that are of great nutritional and physiological importance for the human body, Brazil nuts exceeded poultry meat by the content of $\mathrm{Ca}$ (12 times), Fe (7.4 times), Se (7.2 times), Mg (6.3 times), P and $\mathrm{Zn}$ (3.6 times), as well as $\mathrm{Cu}, \mathrm{Mn}, \mathrm{Co}$, etc.

Table 3 Mineral Composition of Materials Under Study

\begin{tabular}{|c|c|c|}
\hline \multirow[t]{2}{*}{ Element } & \multicolumn{2}{|c|}{ Results of Raw Material Study, mg/kg } \\
\hline & chicken legs & Brazil nut \\
\hline $\mathrm{Ag}$ & - & $0.233 \pm 0.017$ \\
\hline Al & $1.390 \pm 0.092$ & $3.530 \pm 0.240$ \\
\hline As & - & $0.046 \pm 0.003$ \\
\hline $\mathrm{Au}$ & - & $0.792 \pm 0.061$ \\
\hline B & - & $3.381 \pm 0.212$ \\
\hline $\mathrm{Be}$ & - & $0.022 \pm 0.002$ \\
\hline $\mathrm{Ca}$ & $71.550 \pm 6.610$ & $857.410 \pm 54.320$ \\
\hline $\mathrm{Cd}$ & - & $0.020 \pm 0.002$ \\
\hline Co & - & $1.124 \pm 0.097$ \\
\hline $\mathrm{Cr}$ & $0.087 \pm 0.007$ & - \\
\hline $\mathrm{Cu}$ & - & $7.399 \pm 0.510$ \\
\hline $\mathrm{Fe}$ & $4.59 \pm 0.33$ & $33.780 \pm 2.110$ \\
\hline $\mathrm{Ga}$ & - & $0.252 \pm 0.013$ \\
\hline $\mathrm{K}$ & $9254.210 \pm 731.870$ & $3226.007 \pm 194.550$ \\
\hline $\mathrm{Li}$ & $0.017 \pm 0.002$ & - \\
\hline $\mathrm{Mg}$ & $262.900 \pm 21.450$ & $1668.020 \pm 112.440$ \\
\hline $\mathrm{Mn}$ & - & $6.443 \pm 0.421$ \\
\hline Mo & - & $0.078 \pm 0.005$ \\
\hline $\mathrm{Na}$ & $731.610 \pm 53.450$ & - \\
\hline $\mathrm{Ni}$ & $1.070 \pm 0.340$ & $2.639 \pm 0.193$ \\
\hline $\mathrm{P}$ & $2244.220 \pm 204.870$ & $7975.012 \pm 601.210$ \\
\hline $\mathrm{Pb}$ & - & $0.009 \pm 0.002$ \\
\hline $\mathrm{Sb}$ & $0.003 \pm 0.001$ & - \\
\hline $\mathrm{Se}$ & $0.290 \pm 0.020$ & $2.094 \pm 0.110$ \\
\hline $\mathrm{Si}$ & $5.730 \pm 0.410$ & $3.196 \pm 0.251$ \\
\hline Sn & - & $0.142 \pm 0.011$ \\
\hline $\mathrm{Te}$ & $0.036 \pm 0.002$ & $0.857 \pm 0.062$ \\
\hline $\mathrm{Ti}$ & $0.074 \pm 0.005$ & $0.570 \pm 0.040$ \\
\hline $\mathrm{V}$ & - & $0.229 \pm 0.014$ \\
\hline $\mathrm{W}$ & - & $2.112 \pm 0.183$ \\
\hline $\mathrm{Zn}$ & $13.780 \pm 1.240$ & $50.153 \pm 3.276$ \\
\hline
\end{tabular}

It is generally known that a deficiency of mineral elements reduces the activity of antimicrobial defense factors, increases the frequency of respiratory and gastrointestinal diseases, while the lack of $\mathrm{Ca}, \mathrm{Zn}, \mathrm{Cu}, \mathrm{Mn}$ is one of the reasons behind the formation of left ventricular diastolic dysfunction, coronary circulation disorders and ventricular fibrillation (Nagornaya et al., 2012;
Voronov, 2020; Höller et al., 2018). Today, iron deficiency is the most common alimentary-dependent pathology of mankind, associated with impaired immune system functions, an increase in tumor incidence, a decrease in the organism's defense against peroxidation, impaired respiratory functions and the development of tissue hypoxia (Larina, 2019). Selenium deficiency causes disruption of the antioxidant defense system and thus contributes to free radicals affecting lipophilic membranes, leading to the development of thyroid atrophy (Schomburg and Kohrle, 2008; Huguenin et al., 2015).

The levels of heavy metals in nuts - As, $\mathrm{Cd}, \mathrm{Pb}$, not found in semi-finished meat products, did not exceed the regulated norms of TR CU 021/2011.

Chilled chicken legs had a relatively high content of K (2.9 times), Si (1.8 times), as well as $\mathrm{Na}$.

Tasting of laboratory samples of chicken pockets established that the nut had a positive effect on the consumer characteristics of the product (Figure 1). At the same time, the control sample did not have outstanding taste and aromatic properties, creamy tones predominant, leveling the characteristics of a meat product. This is presumably due to the high fat content of butter, since it is known that its main flavoring agents are volatile fatty acids, fatty acid esters, etc (Evsenina and Nikitov, 2019; Porosyatnikov, 2015). In this regard, it is advisable to use butter with $72.5 \%$ fat.

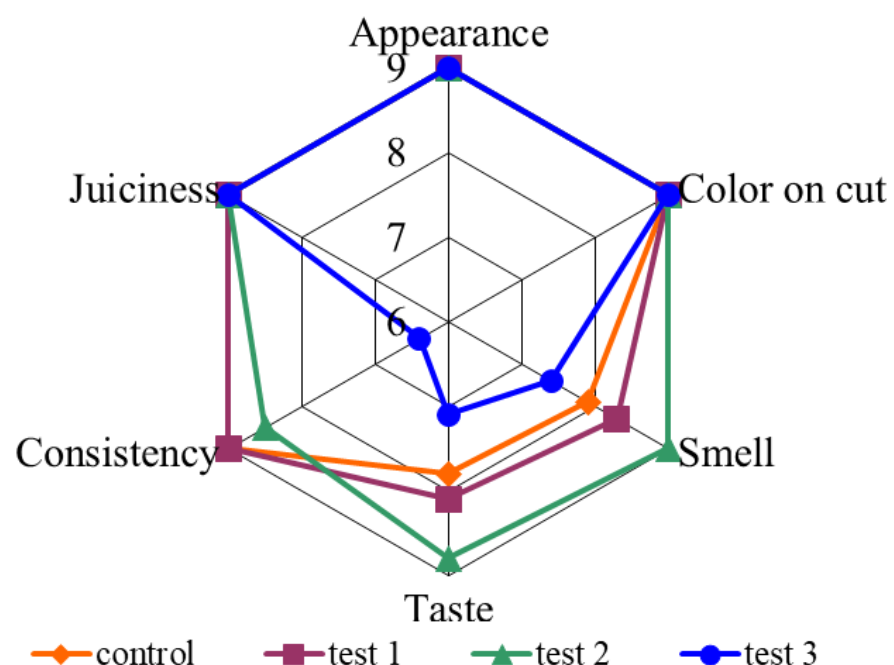

Figure 1 Profilogram of Tasting Evaluation of Laboratory Samples of Chicken Pockets

The addition of the plant raw material in a dosage of up to $10 \%$ improved the taste and aroma properties of the test samples of baked meat products. There appeared some nutty notes, the creamy tone weakened, and thus, the scores for the corresponding indicators increased to 8.8-9.0. However, the presence of sugars and starch in the kernels, used at a dosage of $15 \%$, formed an unusual sweetish accent in test 3 . Moreover, there appeared some powdery consistency, which collectively reduced the final score to 6.4 points.

The appearance, color on the cut, juiciness of all samples were consistently high $-9,0$ points for each indicator. So, according to the results of the tasting, the points were as follows: control $-51.7 \pm 0.2$, test $1-52.4 \pm 0.3$, test $2-53.3 \pm 0.3$, test $3-47.9 \pm 0.2$.

In further studies, we compared the quality and nutritional value of the control sample and test 2, since it was the most successful combination of meat and the plant raw material after the final tasting evaluation. It was revealed that the samples under study did not have significant differences in the content of moisture, fat, table salt (Table 4). But the experimental ones contained somewhat more protein (by 1.9\%) and showed the presence of dietary fiber, which is beneficial from the standpoint of modern nutritional science.

Table 4 Nutrient Composition of Laboratory Samples of Chicken Pockets

\begin{tabular}{lcc}
\hline \multirow{2}{*}{ Indicator } & \multicolumn{2}{c}{ Results } \\
\cline { 2 - 3 } & control & test 2 \\
\hline Mass fraction of moisture, \% & $62.0 \pm 1.5$ & $63.7 \pm 1.3$ \\
\hline Mass fraction of protein, \% & $24.8 \pm 1.1$ & $26.7 \pm 1.2$ \\
\hline Mass fraction of fat, \% & $10.5 \pm 0.7$ & $10.4 \pm 0.8$ \\
\hline Mass fraction of table salt, \% & $1.5 \pm 0.2$ & $1.5 \pm 0.3$ \\
\hline Dietary fiber content, $\mathrm{g} / 100 \mathrm{~g}$, including: & & $0.52 \pm 0.02$ \\
soluble & traces & $0.13 \pm 0.01$ \\
insoluble & & $0.39 \pm 0.02$ \\
\hline
\end{tabular}


The study of the mineral composition of the laboratory samples revealed that the test samples exceeded the control one in terms of the amount of several macroand microelements (Figure 2). Specifically, the samples baked according to the modified recipe had more $\mathrm{Ca}$ (2.2 times), Se (2 times), Fe (1.7 times), Mg (1.6 times), $\mathrm{P}$ and $\mathrm{Zn}$ (by 26\%), as well as $\mathrm{Cu}, \mathrm{Mn}, \mathrm{Mo}, \mathrm{Ag}, \mathrm{Au}, \mathrm{Co}$, etc. which were not found in the control. Ca plays an important role in muscle contraction $/$ relaxation, blood coagulability, enzymatic regulation, $\mathrm{K}^{+}$channel gating, protein stabilization, and signal transduction. Se increases the immunobiologica reactivity of the body and the development of its resistance to anaphylactic shock, inhibits the activity of citrate hydrolase, and enhances the perception of light rays by the retina. Fe is involved in some key physiological functions, including the transport of gaseous molecules such as $\mathrm{O}_{2}$ oxygen (hemoglobin) or gas transmitters such as $\mathrm{NO}$ or $\mathrm{CO}_{2}$, electron transport in mitochondria, and the activity of various oxidation-reduction enzymes. $\mathrm{Mg}$ plays a major role in blood pressure stabilization. It has an effect on a number of ion transport systems $\mathrm{Na}^{+}$ $\mathrm{K}^{+}$-ATPase, calcium pump, $\mathrm{Na}^{+}, \mathrm{K}^{+}, \mathrm{Cl}^{-}$co-transport) and stabilizes the threedimensional structure of proteins and nucleic acids (Voronov, 2020; Ermakov et al., 2018)

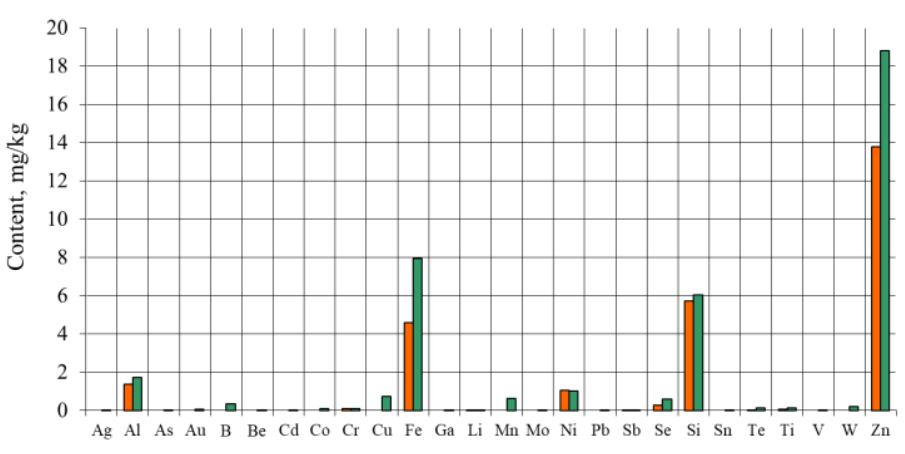

Microelements

$\square$ control $\quad$ atest 2

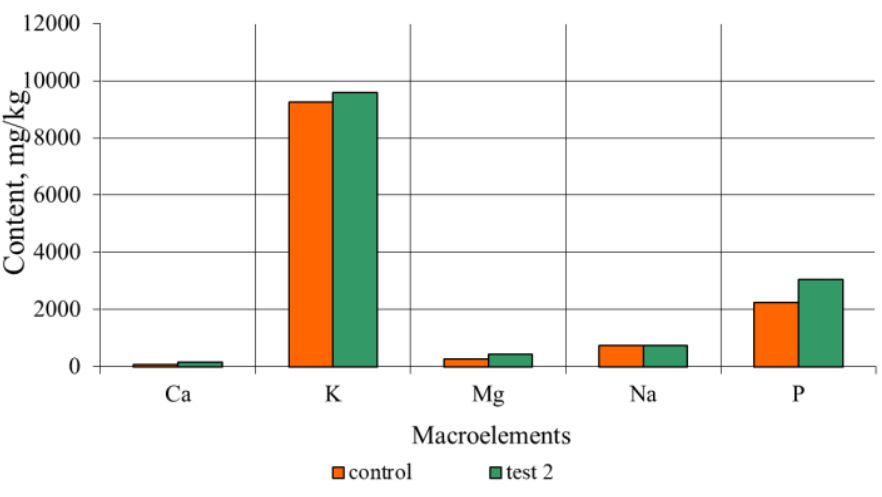

Figure 2 Elemental Composition of Laboratory Samples of Chicken Pockets

Furthermore, the amounts of microelements determined according to MR 2.3.1.2432-08 "Norms of Physiological Needs for Energy and Nutrients in Various Groups of Population of the Russian Federation", if one consumes $100 \mathrm{~g}$ of baked poultry meat products with the addition of Brazil nuts, can satisfy the daily demand of an adult in Se by $82.8 \%$ for men and $105.4 \%$ for women, $\mathrm{K}$ by $38.8 \%, \mathrm{P}$ - by $38.0 \%, \mathrm{Zn}$ - by $15.6 \%, \mathrm{Mg}$ - by $10.7 \%, \mathrm{Fe}-$ by $7.9 \%$ for men and $4.4 \%$ for women, $\mathrm{Cu}-$ by $7.4 \%$.

In the context of the requirements of SanPiN 2.3.2.2804-10 "Additions and amendments No. 22 to SanPiN 2.3.2.1078 "Hygienic requirements for the safety and nutritional value of food products", the product is considered enriched if its average daily portion contains an enriching component in an amount of $10 \%$ (at the end of the shelf life) up to $50 \%$ of the norm of a person's physiological need for it. Thus, $100 \mathrm{~g}$ of a product of a modified recipe can be considered enriched with $\mathrm{K}, \mathrm{P}, \mathrm{Zn}, \mathrm{Mg}$. It is also known that functional food products can contain functional food ingredients, including Se, in amounts up to $300 \%$ of their daily intake (Kodentsova et al., 2010); therefore, the developed meat and plant product can be considered a functional food product.

\section{CONCLUSION}

There was found a relatively high content of lipids, mineral elements $(\mathrm{Ca}, \mathrm{Fe}, \mathrm{Se}$ $\mathrm{Mg}, \mathrm{P}, \mathrm{Zn}$ ), as well as the presence of sugars, starch and dietary fiber in the kernels of the Brazil nut. Adding $10 \%$ of the plant raw material improved the taste and aroma properties of baked meat products, increasesd the content of $\mathrm{Ca}$
(2.2 times), Se (2 times), Fe (1.7 times), Mg (1.6 times), $\mathrm{P}$ and $\mathrm{Zn}$ (by 26\%), and also introduced $\mathrm{Cu}, \mathrm{Mn}, \mathrm{Mo}, \mathrm{Ag}, \mathrm{Au}, \mathrm{Co}$, etc. into the nutrient composition with a decrease in the amount of butter by $8 \%$ as per the recipe. Thus, we established the possibility of using Brazil nut kernels in the technology of functional stuffed meat products.

Acknowledgments: The work was supported by Act 211 of the Government of the Russian Federation, contract № 02.A03.21.0011.

\section{REFERENCES}

Akhmedova, T.P. (2015). Functional Ingredients in Meat Products. Meat technology, 7(151), 16-17.

Amariei, S., Gutt, G., Hretcanu, C.E., Leahu, A., Oroian, M.A., Poroch-Serițan, M., Roșu, A.I. (2016). How properties of edible oils are improved by essential oils, Scientific Study \& Research - Chemistry \& Chemical Engineering, Biotechnology, Food Industry, 17(3), 227-238.

Baturina, A.N., Babenko, I.A. (2019). Organization of production of chicken cutlets with flaxseed in the conditions of the enterprise JSC "Seimovskaya Poultry Farm", Vestnik Nizhegorodskoj gosudarstvennoj sel'skohozyajstvennoj akademii (Bulletin of the Nizhny Novgorod State Agricultural Academy), 4(24), 13-16.

Choi, M.S., Choi, Y.S., Kim, H.W., Hwang, K.E. et al. (2014). Effects of replacing pork back fat with brewer's spent grain dietary fiber on quality characteristics of reduced-fat chicken sausages, Korean Journal for Food Science of Animal Resources, 34(2), 158-165. http://dx.doi.org/10.5851/kosfa.2014.34.2.158

Ermakov, V.V., Tyutikov, S.F., Safonov, V.A. (2018). Biogeochemical indication of microelementosis, M., $386 \mathrm{p}$.

Evsenina, M.V., Nikitov, S.V. (2019). Changes in the fatty acid composition of butter with the introduction of spirulina microalgae into the diet of cows. Izvestiya Dagestanskogo gosudarstvennogo agrarnogo universiteta (Bulletin of the Dagestan State Agrarian University), 4(4), 18-21.

Gorlov, I.F., Slozhenkina, M.I., Fedotova, G.V., Natyrov, A.K., Slozhenkin, A.B., Erendzhenova, M.V. (2020). An innovative recipe for a functional meat product. Industriya pitaniya (Food industry), 5(2), 44-52.

Höller, U., Bakker, S.J.L., Düsterloh, A., Frei, B., Köhrle, J., Konz, T., et al. (2018). Micronutrient status assessment in humans: Current methods of analysis and future trends. TrAC Trends in Analytical Chemistry, 102, 110-122. https://doi.org/10.1016/j.trac.2018.02.001

Huguenin, G.V., Oliveira, G.M., Moreira, A.N., Saint'Pierre, T.D. (2015) Improvement of antioxidant status after Brazil nut intake in hypertensive and dyslipidemic subjects. Nutrition Journal, 14(1), 54 http://dx.doi.org/10.1186/s12937-015-0043-y

Ionescu, A., Aprodu, I., Gurau, G., Banu, I. (2011). Rheology of chickpea protein concentrate dispersions, Scientific Study \& Research - Chemistry \& Chemical Engineering, Biotechnology, Food Industry, 12(4), 387 - 399.

Jamshed, H., Sultan, F.A., Igbal, R., Gilani, A.H. (2015). Dietary almonds increase serum HDL cholesterol in coronary artery disease patients in a randomized controlled trial. Journal of Nutrition, 145(10), 2287-92. http://dx.doi.org/10.3945/jn.114.207944

Kantoroeva, A.K. (2019). Analysis of the development of the world market for nut crops. Ekonomika $i$ upravlenie: problemy, resheniya (Economics and Management: Problems, Solutions), 2(3), 147-154

Klimova, E.V. (2008). Comparative study of total oil content, fatty acid profile, peroxide value, concentration of tocopherol, phytosterol and squalene in the kernels of Brazil nuts, pecans, pine nuts, pistachios and cashews. Pishchevaya pererabatyvayushchaya promyshlennost'. Referativnyj zhurnal (Food and processing industry. Abstract journal), 2, 369.

Kodentsova, V.M., Vrzhesinskaya, O.A., Spirichev, V.B. (2010). Substantiation of the level of food fortification with vitamins and minerals. Voprosy pitaniya (Nutrition issues), 1, 23-33.

Larina, V.N. (2019). Anemia in the practice of a general practitioner: a new look at an old problem. Russkij Medicinskij Zhurnal (Russian Medical Journal), 27(12), 44-50

Lisitsyn, A.B., Chernukha, I.M., Lunina, O.I., Fedulova, L.V. (2016). Legal framework and scientific principles for the creation of functional meat-based food products. Vestnik Altajskogo gosudarstvennogo agrarnogo universiteta (Bulletin of Altai State Agrarian University), 12 (146), 151-158.

Lisovitskaya, E.P., Patieva, S.V. (2016). The use of plant components to form the complexing ability of functional meat products. Vestnik Kazanskogo gosudarstvennogo agrarnogo universiteta (Bulletin of Kazan State Agrarian University), 11(39), 34-38.

Martins, M., Klusczcovski, A.M., Scussel, V.M. (2014). In vitro activity of the brazil nut (bertholletia excelsa h. b. k.) oil in aflatoxigenic strains of aspergillus parasiticus. European food research and technology, 239(4), 687-693. http://dx.doi.org/10.1007/s00217-014-2265-1

Nagornaya, N. V., Dubovaya, A. V., Bordyugova, E. V., Koval, A. P. (2012). Features of the content of macro- and microelements in diseases of the cardiovascular system. Zdorov'e rebenka (Child health), 4(39), 129-135. 
Patent No. 2706159 RF. Cereal bar for nutrition of those working with harmful compounds of arsenic and phosphorus. Kazan National Research University. A.N. Tupolev-KAI (Gumerov T.Yu., Gabdukaeva L.Z., Shvink K.Yu.).

Patent No. 2603892 RF. Method for preparing nut-like mass. Voronezh State University of Engineering Technologies (Rodionova N.S., Popov E.S., Alekseeva T.V., Sokolova O.A., Shakhov A.S.)

Petchenko, V.I., Smagulova, A.K., Aitbaev, A.A. (2016). Quality assessment study and technology development of a functional meat-based product. Vestnik Almatinskogo tekhnologicheskogo universiteta (Bulletin of the Almaty Technological University), 4, 17-25.

Porosyatnikov, A.V. (2015). Chemical composition and nutritional value of butter. Nauka v sovremennyh usloviyah: ot idei do vnedreniya (Science in modern conditions: from idea to implementation), 1, 127-131.

Pyreva, E.A., Safronova, A.I. (2019). The role and place of dietary fiber in the structure of the population's nutrition. Voprosy pitaniya (Nutrition issues), 88(6), $5-11$.

Schomburg, L., Kohrle, J. (2008). On the importance of selenium and iodine metabolism for thyroid hormone biosynthesis and human health. Molecular Nutrition \& Food Research, 52(11), 1235-1246. http://dx.doi.org/10.1002/mnfr.200700465

Simopoulos, A.P. (2010). Genetic variants in the metabolism of omega-6 and omega-3 fatty acids: their role in the determination of nutritional requirements and chronic disease risk. Exp. Biol. Med., 235, 785-795. http://dx.doi.org/10.1258/ebm.2010.009298

Skurikhin, I.M., Tutelyan, V.A. (1998). A guide to the methods of analysis of food quality and safety, M: Brandes: Meditsyna, 341, (In Russian).

Souza, R.G., Gomes, A.C., Naves, M.M., Mota, J.F. (2015). Nuts and legume seeds for cardiovascular risk reduction: scientific evidence and mechanisms of action. Nutrition Reviews, 73(6), 335-47. http://dx.doi.org/10.1093/nutrit/nuu008 Ukkonen, T.I., Belozerova, M.S. (2017). Development of curd cheese with increased selenium content. Materials of the VIII International Scientific and Technical Conference "Low-temperature and food technologies in the XXI century", 264-267.

Voronov, G.G. (2020). Chelated forms of minerals - a step into the future, Retsept (Recipe), 23(1), 131-145. 